\title{
China and Europe: engagement, multipolarity and strategy
}

\section{Terry Narramore}

\begin{abstract}
Ever closer relations between China and Europe over the last decade have sparked speculation about an emerging axis or balance of power vis-à-vis the United States. China, the European Union and its key member states have expressed a preference for a more balanced international order based on multilateral institutions. Despite a rapid and extensive expansion in economic and political relations between China and the European Union, there is no evidence for balancing against the United States in strategic areas. Rather, the variations in the positions of China, the European Union and the United States can more accurately be seen as policy or interest bargaining. Because the European Union does not share US security interests in the Asia-Pacific region, the European Union and its key member states can seem at variance with the US position on China. Bargaining over the failed attempt to lift the European Union's arms embargo against China shows that the European Union and the United States are not so far apart on strategic issues in the Asia-Pacific.
\end{abstract}

Keywords China-EU foreign relations; balance of power; multipolarity; strategy.

\section{Introduction}

China's relations with both the European Union and its individual member states have drawn so close over the past decade that some scholars refer to an emerging China-Europe 'axis' (Scott 2007; Shambaugh 2004a, 2005b). This highly evocative term suggests that China and Europe are beginning to shape a new balance of power, reined against the United States, as part of an emerging multipolar international system. While scholars continue to debate the nature of post-Cold War international relations, there are two key

Terry Narramore lectures in the School of Government at the University of Tasmania (Sandy Bay campus). His research interests include the politics of rights, minorities and identity and the international relations of China, Japan, and the Asia-Pacific. He has published in The Pacific Review, Citizenship Studies and the Australian Journal of Political Science.

Address: School of Government, University of Tasmania, Private Bag 22, Hobart, Tasmania 7001, Australia. E-mail: T.E.Narramore@utas.edu.au

The Pacific Review

ISSN 0951-2748 print/ISSN 1470-1332 online (C) 2008 Taylor \& Francis

http://www.tandf.co.uk/journals

DOI: $10.1080 / 0951274070868930$ 
problems with seeing China-Europe relations in this way. The first is what constitutes balancing behaviour and if there is sufficient evidence for this in the case of China and Europe. The second is the ambiguous status of Europe or the European Union as international actors. Balance-of-power theory's focus on the relative material capability and the alliance or 'axis' relations of states does not adapt well to the multi-state or 'supranational' structure of Europe or the European Union. There may not only be a problem in demonstrating that China and Europe are balancing the United States, but also in expecting this to be a realistic possibility in a relationship of this kind.

Despite several variations in balance-of-power theory, the core argument of most relevance to contemporary international relations is that 'hegemonies do not form in multi-state systems because perceived threats of hegemony over the system generate balancing behaviour by other leading states in the system' (Levy 2004: 37; see also Waltz 1993: 77; 2000: 5-6). The absence of clear rivals to US 'hard' power over almost two decades has not shaken the convictions of some balance-of-power theorists; rather, they have shifted their attention to 'soft balancing'. Soft balancing is said to occur when states 'generally develop ententes or limited security understandings with one another to balance a potential threatening state or rising power' (Paul 2004: 3; see also Oswald 2006; Pape 2005; Walt 2005: 126-32). Although this is a latent version of balancing, it relies on a conceptual link with conventional balance-of-power theory. Soft balancing remains a response to the hegemonic state, conceived as a potential security threat, and foreshadows a major shift in the structure of international politics that goes beyond simple issue-driven 'diplomatic wrangling' (Brooks and Wohlforth 2005: 73, 105).

Although China, the European Union and some of its key member states often speak the language of multipolarity, there is no clear evidence that this amounts to a coalition of hard or soft balancing, let alone an axis, against the United States as a security threat. A fundamental conflict of interest between states - such that they become 'geopolitical rivals' (Brooks and Wohlforth 2005: 76) - needs to be clearly demonstrated in order for multipolar balancing to be demonstrated. Hard balancing suggests significant expansion or aggregation of military capabilities to match a potential threat (Legro and Moravcsik 1999: 14-5). Soft balancing measures 'must plausibly be linked to enhancing [states'] security vis-à-vis the US threat' (Brooks and Wohlforth 2005: 78-9).

Events surrounding the Iraq War in particular led many observers to interpret attempts to frustrate or constrain US policies as signs of balancing. Both China and the European Union 'increasingly understood the Bush administration's policies as a geopolitical problem' and proffered contrasting models of 'non-hegemonic' international power (Callahan 2007: 779; see also Deng 2007: 865-6). But the differences between China and the European Union on the one hand and the United States on the other can be explained by factors that are more 'mundane' than balancing. As some critics of balance-of-power theory note, it is important to 'distinguish policy 
bargaining from balancing' (Brooks and Wohlforth 2005: 75, 79, 104). A different set of national interests was driving each of the main players, shaped by different security concerns and commitments. This can be demonstrated through an examination of the development of the 'strategic partnership' between China and the European Union, which has not yet achieved a clear understanding of common strategic purpose or shared security interests. It can also be demonstrated in more detail in the failed campaign to lift the European Union's arms embargo against China, an issue that, in theory, had the potential to affect the balance of power in the Asia-Pacific region. Initiated primarily by Germany and France, the campaign to lift the embargo was seen by its supporters as a concession to China that would, it was hoped, be reciprocated with efforts 'to expand [China's] relations with the EU on all levels, offering European business favourable treatment when investing and doing business in and with China' (Berkofsky 2006: 109). For China, lifting the embargo was about its prestige and reputation as a rising great power seeking equal status with other great powers. It may have improved its bargaining position through a diversification of arms imports, but China was not seeking to use this issue to develop an alignment that could reduce its autonomy and provoke counterbalancing measures from the United States.

Whereas economic interests primarily determine EU relations with China, strategic interests are a more significant factor in shaping US relations with China, at both the regional (Asia-Pacific) and global levels (Moeller 2002: 30). The US commitment to forward military engagement in the Asia-Pacific, via its bilateral security alliances, and to pre-eminent power at regional and global levels potentially run counter to China's strategic vision for its own peaceful 'rise' or 'development' to the status of a regional power (Abramowitz and Bosworth 2006; Roy 2003: 3-4). China and the United States face security dilemmas over the status of Taiwan, China's regional military role and the US development of Theatre Missile Defence (TMD) (Mastanduno 2005; Van Ness 2002). In contrast, the European Union and its member states 'have no discernable impact on the strategic and institutional balance of the Asia-Pacific' (Godement 2006: 56) and lack a direct interest in regional security issues. They do not play a role in supplying regional security, nor would China want them to do so (Moeller 2002: 31).

Arguments for an emerging alliance or axis between China and Europe are also undermined by the ambiguous nature of the relationship. The European Union lacks the unitary actor status usually associated with balancing behaviour among states. Not only do EU member states adopt different positions on relations with China, but the European Union itself has also failed to gain more popular levels of support from both the European Parliament and key national parliaments on central issues in the partnership. Moreover, the European Union and China hold different interpretations of the strategic partnership and each side has been disappointed in trying to bridge the gap between rhetorical expectations and the art of the possible. 
Far from indicating a potential realignment in the balance of power, the wisdom of hindsight is stimulating more sober assessments of recent ChinaEU relations. If China, the European Union or its key member states are serious about restraining US power in a post-Iraq War world, their hopes for success lie more in convincing the United States that this serves its longterm interest (Brooks and Wohlforth 2005: 75) than in promoting strategic partnerships that hint at the promise of a new balance of power.

\section{The place of Europe in China's strategic outlook}

At the heart of China's relations with the European Union lie two key strategic issues. First and foremost is China's objective of regaining its rightful place as a 'great power' (da guo) (Chambers 2006: 67-8; Zhang and Tang 2005: 48-9). Second, there is the question of the best means for China to articulate its rising power through the international arena. China's quest for great power status is a long-standing one, but over the last thirty years of the reform era China's public discourse on how it proposes to achieve this status has become progressively more moderate. China has not always been able to resolve the tension between these two issues. The paramount power of the Chinese Communist Party (CCP), its continuing sensitivity to issues of territorial sovereignty (primarily Taiwan), and its realist concern with wedding economic power to military capability creates doubt about China's intentions (Pei 2006; Van der Geest 2006). But China has devoted considerable diplomatic effort into dispelling such doubt via what some scholars describe as a 'reassurance' strategy (Goldstein 2005; Jia 2005; Zheng 2005). This strategy aims to continue China's path to great power status through co-operative engagement with the global economy and the international system of states, while trying not to 'provoke counterbalancing actions', particularly from the United States (Chambers 2006: 67; Christensen 2001; Goldstein 2005; Swain and Tellis 2000).

As part of its 'reassurance' China has gradually softened public statements on its great power strategy and ambitions. Under Deng Xiaoping's leadership China stressed the safeguarding of sovereignty issues associated with the Five Principles of Peaceful Co-existence (Chambers 2006: 67, 101). ${ }^{1}$ Deng himself advised China: 'conceal one's capacities and foster obscurity, while achieving some things' (tao guang yang hui, you sou zuo wei), and 'do not seek leadership' (bu yao dang tou) (Shambaugh 2005a: 12; Zhang and Tang 2005: 49). In Jiang Zemin's era this obscurantism was replaced with the 'new security concept' (xin anquan guandian), which posited a co-operative alternative to a US-led 'Cold War' international order and aimed to convince states in the Asia-Pacific that China was not seeking regional hegemony (Gill 2005: 260-2; Roy 2003: 1-4). Similarly, the notion of a 'peaceful rise' (heping jueqi) that promoted a non-coercive, multilateral approach to China's expanding power has recently been superseded by less confronting notions of 'peaceful development' (heping fazhan), a 'harmonious society' 
(hexie shehui), and a 'harmonious world' (hexie shijie) (Glaser and Medeiros 2007: 297-301).

China's often stated preference for a multipolar world order has also been moderated in recent years. Although official statements routinely referred to multipolarization (duоjihua) as a 'historical trend independent of human will', and the inevitable product of the 'democratisation of international relations', it was not clear what this implied for a future international order (see, for example, MOFA 2004). It appeared to exclude rising powers like Japan and India, and there was no clear consensus among China's foreign policy community on whether multipolarity required balancing, bandwagoning with, or constraining the United States. The discourse of multipolarity was in part designed to 'sooth nationalist pressures' in China (Hughes, C. R. 2005: 124), and over the past few years it has declined relative to discussions of the pressures of 'globalization' and how best to respond to it (Johnston 2003: 30-6).

The central message in this evolution towards a reassurance strategy is that 'China is not a revisionist state that will destabilise the international system as it revitalises itself' (Glaser and Medeiros 2007: 309). China's new leadership has concluded that in the near to medium term it has no realistic alternative to working through the existing arrangements of international politics. As a result, China has become an increasingly active diplomatic player at the global level and especially in its own region, seeking positive relations at bilateral and multilateral levels (Fullbrook 2007; Shambaugh 2004b). Any discussion of China and the European Union forming a multipolar balance of power needs to bear China's recognition of its limitations in mind.

The development of a strategic partnership between China and the European Union conformed to the broad objectives of a reassurance approach. From the mid-1990s onwards China developed similar partnerships with a range of states - the great powers and rising states gaining most attention and more recently these have been extended to regional organizations such as ASEAN and the European Union (Gill 2007: 58-63). China sought to enhance its own international position through closer relations with other great powers while protecting the autonomy that could be sacrificed through alignment with any one state or regional organization (Deng 2007: 866, 892-4; Goldstein 2001: 846). For the moment China wants to convince its 'partners' that it can make the transition to equal great power status in a nonconfrontational way that consciously eschews balancing against a third party (Goldstein 2005: 39-40; Shih 2005: 764-5). In this context China interprets 'strategic' in rather anodyne terms as, in Wen Jiabao's words, 'long-term and stable, bearing on the larger picture of China-EU relations', on 'both bilateral and multilateral levels' (Wen 2005; see also Godement 2006: 63).

China came rather late to engagement with the process of European integration and was slow to recognise the European Union as a significant international actor. It was not until 1998 that annual summits began, followed in 2001 by a 'full partnership'. China's brief policy paper on the European 
Union appeared only in October 2003, in response to the European Union's September paper. China's position gave little attention to the international balance of power. It was equivocal on multipolarity, merely stating that the 'trend towards world multipolarity and economic globalization is developing amid twists and turns' (Callahan 2007: 788; MOFA 2003). It attached 'importance to the role and influence of the EU in regional and international affairs' but implicitly acknowledged that the European Union had no direct bearing on China's security, noting that there was 'no fundamental conflict of interest between China and the EU and neither side poses a threat to the other' (MOFA 2003).

At a more pragmatic level, a full range of economic, political, social and cultural exchanges were outlined in China's policy paper, and these have indeed developed to a point where the European Union is now China's largest trading partner. Two-way trade in 2005 was worth $€ 210$ billion. China continues to enjoy a large trade surplus with the European Union: €106 billion in 2005 (EU 2007a). China's trading pattern - transforming high levels of resource imports into manufactured goods for domestic and export markets - followed the path of Japan, but became more dependent upon foreign investment and technology transfer. Almost half of the exports from East Asia (excluding Japan) to NAFTA and the European Union come from China (Lampton 2005: 310), with foreign investment accounting for over 40 per cent of China's GDP (Hale and Hale 2003: 38). The advanced economies of EU member states represent vital export markets and sources of investment and technology for China. China also benefits from extensive research and development agreements with the European Union, including participation in the Galileo radio-satellite navigation system to the tune of a $€ 200$ billion investment (EU 2003). The United States is concerned about the potential military applications for China of such technology exchanges, but at this stage it remains unclear exactly what level of access China will be given to potentially sensitive projects like Galileo (Casarini 2006: 28; Jones and Larrabee 2006).

Over a range of issues, then, China and the European Union have established 'deeply institutionalized dialogue channels' (Gill 2005: 254). On diplomatic, security and military matters, however, there is little beyond the expression of China's usual national sovereignty concerns and the desire to promote international co-operation through bilateral and multilateral forums. In summary, China wishes the European Union to:

- recognize China's market economy status;

- strictly observe the one China policy (not encourage Taiwan's independence);

- not encourage Tibetan separatist tendencies;

- continue the dialogue process on China's human rights;

- increase co-operation on counter-terrorism, arms control, nonproliferation and non-traditional security threats; 
- strengthen bilateral and multilateral co-operation (annual summits, AsiaEurope Meeting, World Trade Organization, United Nations).

China's policy paper leaves military matters until last, and only then requests the lifting of the embargo on arms sales to China (MOFA 2003). These remain the abiding themes in China's view of the relationship to the present (see, for example, MOFA 2006). ${ }^{2}$ While official documents may seldom betray any multipolar ambitions, there was no clear evidence for anything other than China's strong desire to maintain territorial integrity and its belated recognition that multilateral forums may increase its relative influence in regional and global affairs. Even China's references to multilateral co-operation were relatively modest, focusing on economics and the 'multilateral trading regime' (Callahan 2007: 788). Moreover, a preference for multilateralism does not add up to multipolar balancing (Brooks and Wohlforth 2005: 74, 82-3).

Where China has failed to gain satisfaction from the European Union, it has sometimes complained about political discrimination. This goes to the heart of China's pursuit of sovereign equality in great power status and prestige through its strategic partnerships (Deng 2007). China's attitude to the European Union's postponement of market economy status and the lifting of the arms embargo should be seen primarily in this light (Golden 2006: 289-94). The embargo particularly upset China because it placed it alongside Burma, Sudan and Zimbabwe. It was seen as a lingering stain on relations, and China frequently declared that rapid increases in arms sales were not expected upon its removal. Lifting the embargo would show that 'the EU does not discriminate against Beijing but treats it on a par with nations such as Russia' (Casarini 2006: 30; see also Huo 2005). For China, long-standing security dilemmas with the United States and its allies, particularly the military balance across the Taiwan Strait, were bound to cloud the issue of arms imports from Europe. But the post-Cold War predominance of the United States did not precipitate the stand off with China and thus even a potential increase in European arms sales to China is not causally related to it (Brooks and Wohlforth 2005: 87). For the moment, China and the United States are holding the status quo and discouraging declarations of de jure independence. China's main priority is to staunchly uphold the 'one China' policy, not to cajole the EU and its member states into a co-operative arms build-up against the United States over Taiwan. In the end, China was sorely disappointed that the European Union failed to deliver on what may have seemed like a promise to lift the embargo (Callahan 2007: 789). It discovered the 'hard way' the European Union's inability to perform as a unitary actor on this issue (Berkofsky 2006: 105).

Over the longer term China may also be hoping to increase its 'bargaining leverage' over Russia - which supplies around 80 per cent of China's military equipment, conservatively valued at US $\$ 5$ billion - and the United States, whose arms suppliers would be expected to lobby for wider access to the 
China market if the EU embargo were to be lifted (Brooks and Wohlforth 2005: 83-8; Tang 2005: 320). But for the near to medium term, European arms suppliers cannot compete with Russia on price and technology transfer (Casarini 2006: 34).

With the failure to lift the arms embargo, China subsequently 'reevaluated' its approach to Europe, shifting some of the focus from the EU Commission back to the key member states (Callahan 2007: 789). In the past China has not been above punishing those states that transgress its sovereignty issues: the Netherlands and Denmark, for example, over arms sales to Taiwan and criticism of human rights, respectively. France, on the other hand, has been rewarded with commercial contracts for opposing negative rulings on human rights issues (Baker 2002; Sandschneider 2002: 43-4). Although such divide-and-rule tactics declined as China engaged in a more proactive diplomacy towards the European Union, China might still exploit differences between the EU member states in defence of its core concerns (Casarini 2006: 18-19). As things stand, China tends to believe that the European Union 'does not yet need to be taken seriously as a foreign and security policy actor with the influence and capabilities to threaten regional security' (Berkofsky 2006: 108).

Finally, although a multipolar strategy would suggest that China encourages a rivalry between the United States and its formal alliance partners - beginning with economic rivalry between them (Moeller 2002: 31) - it has quietly pursued dialogue with NATO, particularly over its presence in Afghanistan and Central Asia. This may reflect China's concern about the US role in the region, but does not rule out a shared interest in counterterrorism and the wider stability of the region (Garver 2005: 213; Weitz 2006; Zhang 2003). Indeed, low-level security co-operation between China and the United States has continued, with joint search-and-rescue exercises in November 2006 (Zhao and Liu 2007: 591).

For China, then, the European Union has developed into one of its most important international partners. The EU process provides a multilateral forum through which China has the potential to advance its national interests. There may not be any 'fundamental conflict of interest' between China and the European Union, but precisely because of China's presence in the AsiaPacific the relationship cannot avoid the strategic and security issues of that region.

\section{(A few) guns and butter? Strategic implications of Europe's engagement with China}

Europe is still in the throes of a long-term experiment to see how far its states are prepared to 'pool' their sovereignty for the sake of peace and stability. The reconciliation between France and Germany, and between Eastern and Western Europe, has reduced the potential for damaging security dilemmas and raised the prospect of a regional approach to security through 
the European Union's Security and Defence Policy (ESDP). As the most jealously guarded aspect of sovereignty, it is no surprise that state security still takes priority over regionalization and that the European Union faces considerable constraints upon building defence capacity. Among the key European states of the United Kingdom, Germany and France, different attitudes to the appropriate role of the United States, NATO and the European Union in security matters still exist, as the Iraq War demonstrated (Piper 2005: 77). Europe's most serious security challenges tend to devolve to military interventions in internal state conflicts, such as those in the Balkans, and these have required US support through NATO. Developing an independent force to match US capabilities faces planning and resource difficulties and current attempts appear at best to be complementary to US capability. If the EU states are serious about closing the gap with the United States they face prohibitive costs that at the moment they are not prepared to accept. As a result, none of the member states see the ESDP as a central part of their security policy (Brooks and Wohlforth 2005: 91-3; Winn 2003).

Notwithstanding the problems in building a regional defence capacity, the European Union has not had to confront the security dilemmas of the Asia-Pacific region directly. Cold War legacies remain in the North Korean regime, Vietnam, China's claim to Taiwan and, to a lesser degree, the CCP's rule of China itself. There are still no collective security agreements in the region. The US-led hub-and-spokes system of bilateral security alliances, established to contain communism in the region, is not in post-Cold War retreat (Mastanduno 2005). Rather, it is broader in scope - taking its members to combat zones in Afghanistan and Iran - and has an enhanced military capability, with most members increasing defence spending or upgrading military technology. In part, this expansion in military capability is in response to China's modernization of its own armed forces (Hartfiel and Job 2007). Neither the European Union nor its member states play a direct role in maintaining the US bilateral security system, leading some cynics to note the European Union's incentive to 'free ride' on US hegemony in the region (Deng 2007: 897-8). When discussions of possible multipolar balancing by the European Union and China are therefore raised, can this really mean expanding European and Chinese capabilities to be able to match the United States in both Europe and the Asia-Pacific?

A relative lack of security constraints gave the European Union considerable room to manoeuvre in negotiating relations with the Asia-Pacific in general and China in particular. The European Union's initial discourse on becoming a 'strategic partner' with China provided a good example. EU policy makers 'have remained rather vague with regard to the concrete objectives and purpose of the strategic partnership' (Casarini 2006: 25), and this lack of clarity left considerable scope for a permissive optimism. Such optimism was the key weakness in the European Union's strategy of engagement, as reflected in the Commission's 2003 China policy paper. Engagement permitted the European Union to continue primarily economic 
relations with China while not confronting the more difficult political and security issues. The paper acknowledged differences on human rights and governing systems, but overestimated the capacity of EU engagement to effect a positive transition in China's development. Javier Solana's statement on European security strategy had already argued that '[t]rade and development policies can be powerful tools for promoting reform' (Solana 2003: 10). The European Union's paper echoed this theme, noting:

Europe thus has a major political and economic stake in supporting China's transition to a stable, prosperous and open country that fully embraces democracy, free market principles and the rule of law. The EU has much to offer here, stemming in part from its own experience in integrating accession countries from East and Central Europe.

(EC 2003: 3; see also Callahan 2007: 788, 790-6)

The idealist tenor of such engagement allowed the question of China's transformation through partial 'Europeanisation' to be displaced to an unspecified future: a 'future imperfect' (Callahan 2007: 790). The Commission's optimism also exaggerated the sense of shared interests and the ability of the European Union to speak 'with a single voice' in the strategic partnership (EC 2003: 7; Moeller 2002: 11).

In summary, the Commission's 2003 paper set out the basic framework for deepening EU engagement with China on four key levels:

- Strategic partners: working from shared interests to promote mutual political dialogue, both bilaterally and multilaterally on the international scene';

- Support for China's transition to an open country that embraces democracy, the free market, and the rule of law (with respect for human rights);

- Encouraging China's economic and social reforms and its integration into the global economy (through the WTO);

- Increasing the visibility of the EU in China.

(EC 2003: 3-4)

In terms of working as 'strategic partners on the international scene' (EC 2003: 7) the Commission highlighted a shared interest in 'multilateral organizations and systems', or 'effective multilateralism,' and 'joint security and other interests in Asia and elsewhere' (EC 2003: 7, 23). Yet neither the European Union's multilateral vision nor its security interests made a good match with those of China.

To begin with, the European Union denied that working as 'strategic partners' was meant to imply multipolar balancing. In the words of Benita Ferrero-Walder, the European Union's External Relations Commissioner: 'it is not the number of poles which counts, but rather the basis on which they 
operate. Our vision is a world governed by rules created and monitored by multilateral institutions ... for putting the world in good, multilateral order' (Ferrero-Walder 2005). The European Union was also unclear in setting out the implications of 'effective multilateralism'. China's approach to multilateralism falls far short of EU-style experiments in pooling sovereignty and regulating the affairs of member states. Rather, China's staunch defence of principles of national sovereignty and non-interference in the domestic affairs of member states is well matched to ASEAN's principles, which helps explain its activism in that arena (Fullbrook 2007). China has also shown a reluctance to support UN-sponsored sanctions or interventions against energy suppliers like Iran and Sudan (Berkofsky 2006: 110-2; Odgaard and Biscop 2006: 5-15; Stumbaum 2007: 362-6). Finally, China's continuing sensitivity on issues of sovereign territory (primarily Taiwan) narrows the opportunity for practical security co-operation with the European Union. Co-operation may be limited to UN peacekeeping operations that do not confront these sensitive issues; for example, in such areas of 'human security' as poverty relief, pandemics and natural or environmental disasters (Stumbaum 2007: 367). At this stage, China-EU security co-operation has not progressed beyond the level of dialogue (Odgaard and Biscop 2006: 16).

Thus when the European Union declared a preference for multilateralism in common with China, it appeared to share little more than an ill-defined view of this being a better vehicle for advancing each other's interests than US unilateralism. Yet the variation in perceptions of multilateralism and relative absence of shared security interests also appear to remain unaddressed. It would therefore be misleading to interpret these aspects of the strategic partnership as evidence of an emerging multipolar balance against the United States.

The potential for any form of alliance or 'axis' between China and the European Union must also confront the ambiguous actor status of the European Union. The European Union increasingly sets broad policy approaches and represents member states in creating framework agreements on economic relations (Weinrod 2006: 18). It also attempts region-wide representation through the still immature ASEM process (Loewen 2007). But significant variations remain between member states in their approach to China. Even in economic relations member states pursue their own trade and investment agreements with China at a bilateral level (Casarini 2006: 16-9). France, Germany and the United Kingdom have been the most active in security dialogue and military exchanges (Shambaugh 2004a: 243-4).

Indeed, security issues have exposed some of the fundamental problems for the European Union in representing itself or 'Europe' as a regional actor in relations with China. This can be demonstrated through a brief analysis of one of the most sensitive issues in China-EU relations: the contentious arms embargo on China. Although the failure to lift the embargo makes it difficult to speculate about the effects of a reversal of policy, a future lift is unlikely to upset the prevailing military balance. Nor is there convincing 
evidence that the campaign for a lift was driven by an imperative to balance against US hegemony. Rather, the arms embargo issue reveals a complex, multi-level bargaining over interests at domestic, regional and international levels. The European Union faced bargaining pressures between and within its own member states. France and Germany drove the campaign to lift the embargo in anticipation of deeper economic relations with China. Most importantly, the European Union faced pressure from the United States seeking to maintain its strategic interests in the Asia-Pacific region and prevent a potential break out in arms sales to China, including from its own suppliers.

The European Council imposed the arms embargo - and a suspension of military co-operation - on China in the wake of the brutal suppression of the June 1989 pro-democracy demonstrations in Tiananmen Square. But the Council ruling failed to clarify the meaning and exact terms of the embargo, leaving member states to interpret it in their own way, and they soon resumed their arms trade with China as if these events had not occurred. Unable to regulate the arms industries of member states on a region-wide basis, the European Union made progress in the 1990s on monitoring arms exports. Debates on the need to control the abuse of dual-use technology succeeded in moving the arms issue from the Common Foreign and Security Policy (CFSP) pillar to the European Community pillar, the 'supranational' arena where qualified majority voting can apply. In June 1998 the European Union adopted a Code of Conduct on Arms Exports as a guide to member states on which arms were banned for export, and in June 2000 they introduced a binding Dual-use Regulation (Casarini 2006: 375-7). In a typical example of states defaulting from the European Union on security matters, the Code of Conduct was not legally binding (Tang 2005: 318). Nonetheless, four of its eight criteria for banning exports were considered obligatory. These were that arms sales should not: be used for internal repression; provoke internal conflicts; be a factor in aggression toward another state; or contradict international agreements or UN embargos. Compliance with the Code was also subject to annual review (OJ 2005, 2006).

Despite these pressures to conform to common EU standards on arms exports, the retention of national jurisdiction gave member states considerable latitude in responding to the Code of Conduct. Competition between states over relative compliance encouraged lowest-common-denominator advantage seeking, and their practice fell short of the standards that the Code aimed to achieve (Bauer 2004; Bauer and Bromley 2004: 8-14; Erickson 2005; Wulf 2004: 118). As a result there was a patchwork of national interpretations of the Code: some states read it 'indulgently' (France, Italy, the United Kingdom and Czech Republic) while others adopted a stricter line (Germany and Spain) (Casarini 2006: 376, n. 21; Kogan 2005: 27-30). None of these states could be accused of opening the floodgates in arms sales to China, but a steady trade (see Table 1) continued down to the present. 
Table 1 Value of major EU arms export licences to China ( $€$ million)

\begin{tabular}{lcrrr}
\hline & France & UK & Italy & EU total \\
\hline 2002 & 105 & 80 & 23 & 210 \\
2003 & 172 & 112 & 127 & 416 \\
2004 & 169 & 341 & 2 & 341 \\
2005 & 150 & 88 & 0.4 & 241 \\
Total & & & & 1,208 \\
\hline
\end{tabular}

Source: Adapted from Tang (2005: 318); OJ (2005, 2006).

China's campaign to lift the embargo began soon after the release of its first 'Policy Paper on the EU' in October 2003 (Tang 2005: 318). China's officials frequently attempted to reassure the EU Commission that they had no intentions of using Europe as a major arms supplier (Casarini 2006: 30). At the same time, as the world's largest importer of arms, China sought new arms purchases as a way of modernizing its conventional weapons systems, an area where European manufacturers could potentially be most useful. China also looked to Europe in the hope of developing advanced technology with potential application in early warning capabilities, commandand-control systems, communication, surveillance and satellite navigation. China's investment in the Galileo project was merely the most prominent among several joint technology developments, many of which involved a 'spin off' for the European Union into commercial areas (Anthony 2005; Archick et al. 2005: 13-8; Kogan 2005: 29-30).

In the wake of China's campaign, France and Germany broke ranks with the EU position at the end of 2003. Gerhard Schroeder and Jacques Chirac attempted to 'railroad through' a lifting of the embargo at the Council of Ministers (Patten 2005: 275). Although unsuccessful, they set off a long, drawn-out campaign for a change of policy. The European Union debated the issue throughout 2004 before announcing the intention to lift the ban around spring 2005. This in turn provoked campaigns within the European Union and, more importantly, from the United States to keep the embargo in place. When China passed an anti-Secession Law in March 2005, aimed against supporters of Taiwan's independence, the European Union found a justification for not lifting the embargo, seeing it as a threatening gesture that could damage regional stability (Tang 2005: 318-9). The European Union had gone full circle, promising to lift the embargo on the condition of a 'significant Chinese gesture in the human rights field' and a more effective Code of Conduct (Boese 2005; EC 2006: 11; Patten 2005: 278).

The European Union was divided within itself on lifting the embargo. France was the most active in promoting closer relations with China, declaring 2004 the 'Year of China' and holding joint naval exercises in March the same year (Shambaugh 2004a: 243, 245; Umbach 2004: 4-6). Their economic 
interests in China primarily drove France, Germany and the United Kingdom, and each, along with Italy, had an interest in arms sales to China. At the same time, there was no clear evidence that the arms industry was driving the behaviour of the largest arms exporting states because the embargo did not prevent sales going ahead. The expectation of an expansion in general economic relations with China, with the large EU trade deficit in mind, carried most weight with these states (Patten 2005: 277). They tended to see China as 'just another market' (Casarini 2006: 378). Spain, Finland and the Netherlands also signalled support for lifting the embargo (Butler 2006; Casarini 2006: 30; Tang 2005: 318-9; Umbach 2004: 4-6). Those in favour of the lifting of the embargo argued that, since arms sales were proceeding in any case, it would be better to make the Code of Conduct more transparent, perhaps allowing for greater control over exports to China (Patten 2005: 276-7; Tang 2005: 320). The Scandinavian states, particularly Denmark and Sweden, consistently opposed lifting the embargo on human rights grounds, while the smaller states of Eastern Europe felt more secure remaining loyal to their perceptions of US interests. The European Parliament reflected a broader unease among the European populous about China's human rights record, passing non-binding legislation in 2005 to retain the embargo, making the Code of Conduct binding, and regularly censuring China for failing to make progress on human rights. Germany's own parliament voted against the proposed EU lift (Casarini 2006: 30-2; EP 2005, 2006; Umbach 2004: 4). These divisions make lifting the embargo with transition to a binding Code of Conduct a difficult political task into the future.

The most significant factor in postponing the decision to lift the arms embargo was US pressure. Once aroused, the US response to the French and German campaign was swift and extensive (Berkofsky 2006: 110-1). President Bush and Secretary of State Condoleezza Rice made their objections known during visits to Europe in February 2005. The State Department, Pentagon and intelligence staff provided various briefings and presentations to EU member states (Record 2006). The US Congress held inquiries into the issue and both the House and Senate passed resolutions expressing their strong reservations. The US position was based on four key arguments. First, expanding arms sales to China could allow it to rapidly upgrade weaponry and alter the military balance in the Taiwan Strait, with the possibility of using these weapons against the US military in the region. Second, it would signal that China could import arms while not having to improve its human rights record. Third, there was a danger of the European arms trade feeding weapons proliferation through China. Finally, European defence ties with the United States could mean that US weapons technology could find its way to China and increase pressure from the US arms manufacturers to be allowed to trade directly with China (Archick et al. 2005: 4-11; Grimmett and Papademetriou 2005: 9-10; Sandschneider 2006: 45; Tang 2005: 319). At the time it was reported that the United States itself provided around 6.7 per cent of China's imports of military equipment, compared to 
Europe's 2.7 per cent, but the United States did not provide high-grade arms or sophisticated weapons systems (The Economist 2005; Patten 2005: 276). Since the 11 September terrorist attacks, the United States had moderated its own criticism of China's human rights record in return for co-operation on the 'war on terrorism' and pressuring North Korea into the Six-Party talks to dismantle its nuclear weapons program (Archick et al. 2005: 4-5; Zaborowski 2006b: 88-90, 98-9). It was also possible that European arms manufacturers feared the costs of US-imposed sanctions against them if the embargo was lifted (Bitzinger 2004: 2-3; House 2005). Although not passed into law, in May and July 2005 the House passed bills that would require the Defense and State Departments to sanction any firms transferring arms or dual-use items to China that were banned under international export control agreements. A similar message was sent to Israel, another key arms supplier to China, when the United States suspended joint military development projects and pressured Israel into a memorandum of understanding on arms exports to China (House 2005; Pomper 2005: 34).

Rather than being a flanking move against an emerging China-EU axis, US action asserted the priority of its regional security policy over an EU policy that did not confront the security implications of closer relations with China (Berkofsky 2006: 113-5; Sandschneider 2006: 46-7; Zaborowski 2006b: 84-5, 98-9).

As a loyal US ally, with its own security concerns in the Asia-Pacific region, Japan also opposed lifting the arms embargo. Sino-Japanese relations soured during the Koizumi prime ministership, while Japan's strategic relations with the United States expanded and became more intricate. Japan did not want to see China-EU relations driving a wedge between itself and the United States as its key guarantor of security (Hughes, C. W. 2005: 44-5; Tang 2005: 319).

Faced with internal division and the united front lobbying of the United States and its key Asia-Pacific ally in Japan, the European Union had to accept a diplomatic defeat on lifting the arms embargo in 2005. The member states pushing for a lifting, particularly France and Germany, failed to prepare the political ground for a consensus and were unable to overcome the European Union's inherent problems with collective action. Moreover, they received a stern lesson about the security interests of the United States and its allies in the Asia-Pacific. Since then, there have been a number of adjustments to the European Union's strategic outlook towards China and the region. Despite the European Union's assurances to China that it will 'explore the possibilities for building a consensus for lift [sic]' (EC 2006: 11), it appears to have accommodated the primary concerns of the United States in stating that '[c]urrent and incoming Presidencies should finalise technical preparations to ensure lift $[s i c]$ would not lead to a qualitative or quantitative increase in arms sales' (EC 2006: 11). Recent EU policy statements are more cautious about the potential of the strategic partnership with China (EU, 2007b). Echoing US concerns, the Commission states that lifting 
the arms embargo is conditional upon 'progress on China's human rights situation; working to improve cross-straits relations; and ... improving the transparency of its military expenditure' (EC 2006: 11). Human rights conditions in particular have firmed into a default set of expectations, as stated by the European Union's External Relations Commissioner, Ferrero-Walder: China's ratification of the UN Covenant on Civil and Political Rights; freeing those jailed for involvement in the 1989 Tiananmen Square demonstrations, and; abolition of the 're-education through labour' system of imprisonment without trial (BBC 2007). On the key security issues - arms transfer, Taiwan, China's lack of military transparency, and non-proliferation - the European Union and the United States no longer seem so far apart (EC 2006: 11-2). Moreover, a significant by-product of the failed campaign to lift the embargo was the initiation of regular EU bilateral 'strategic dialogue' with both the United States (from 2004) and Japan (from 2005) on security issues in the Asia-Pacific region, the emphasis being on China (Berkofsky 2006: 109-10). The forces in favour of a lifting of the embargo have also lost considerable political momentum, with Gerhard Schroeder giving way to Angela Merkel and Jacques Chirac to Nicolas Sarkozy, and both new leaders declaring that the embargo should remain in place for the time being (EU Business 2007; Kemenade 2007; Record 2006). Even the European Union's normally optimistic opinion and discussion papers on China have begun to reflect a more cautious approach to the limitations of the 'strategic partnership' (Berkofsky 2006: 103, 104; Casarini 2006; Zaborowski 2006a). The European Union's occasional 'shopkeeper' diplomacy (Patten 2005: 276) is now more fully appraised of the political difficulties involved in changing a policy that must also take into account the security interests of the United States and its key allies in the Asia-Pacific region.

\section{Conclusion}

The debate over what kind of international politics has emerged to replace that of the Cold War is close to two decades old, with no sign of clear consensus. There is broad agreement on the predominance of US power, but this is variously described as unipolar, hegemonic, hierarchical and imperial (Kan 2004; Walt 2005: 13-62). Arguments in support of multipolar balancing against the United States come out of realist theory that is heavily weighted towards equilibrium in international politics. Yet the usual realist test for balancing should be a severe one. It implies clear and significant shifts in material capabilities to match or exceed a hegemonic rival or security threat. Even those arguments that 'soft' balancing is occurring need to demonstrate that perceptions of direct threat and preparations for 'hard' (military) balancing are driving attempts to constrain US hegemony.

Although China and the European Union have at times declared a preference for a multipolar world, their ever closer relations do not provide evidence for this kind of balancing, let alone an emerging 'axis'. Their stated 
preference amounts to little more than support for multilateral decision making through existing international organizations rather than an alternative order, and there is not even a common understanding of what notions such as 'effective multilateralism' might mean for each side. Where their interests touch on security issues - such as arms transfers and dual-use technology in relation to China - Europe's position varies from that of the United States mainly because it does not share the United States' direct security interests in the Asia-Pacific region. The United States is committed to maintaining this formidable forward presence in the region through its bilateral security alliances. Like Europe, the United States now has significant economic relations with China, but sees China as a potential challenger to its strategic presence in the Asia-Pacific. This dualism explains the US policy of engagement with China while at the same time 'hedging' with a potential containment or constrainment of China in the region (Bersick 2006; Jia 2006). The states pushing to lift the EU arms embargo against China are driven primarily by their bargaining for an expansion in economic relations with China and not by balance-of-power considerations. What these states did not fully appreciate was the strength of will in the United States to preserve its strategic interests in the Asia-Pacific.

There is now evidence that the European Union in particular has moved towards incorporating the strategic concerns of the United States as a result of the arms embargo affair. The Commission's recent policy statements reflect a similar outlook to the United States on Asia-Pacific security issues, despite its stated commitment to work towards lifting the embargo. There is an apparent need to broaden the strategic dialogue between Europe and the United States on Asia-Pacific security begun in the wake of the push to lift the embargo (Record 2006). Moreover, if China's strategic role in the region is to be better understood, and perhaps even managed in a way that minimises tension, there is a need to develop trilateral security dialogue between China, Europe and the United States, and some tentative steps have been taken in that direction (MOFA 2007).

\section{Acknowledgements}

The author would like to thank two anonymous referees and Professor Shaun Breslin for their insightful comments on earlier drafts of this article.

\section{Notes}

1 The Five Principles are: sovereignty and territorial integrity; mutual nonaggression; mutual non-interference in each other's internal affairs; equality and mutual benefit, and; peaceful coexistence.

2 In this speech at the 6th ASEM summit in Helsinki in September 2006, Wen Jiabao (MOFA 2006) also mentions the importance of co-operation with Europe on energy security, a more recent, but central concern for China (see Zweig and Bi 2005). 


\section{References}

Abramowitz, M. and Bosworth, S. (2006) 'America confronts the Asian century', Current History 105(690): 147-53.

Anthony, I. (2005) 'Militarily relevant EU-China trade and technology transfers: issues and problems', Conference Paper, Solna, 21 June, Stockholm International Peace Research Institute, Sweden.

Archick, K., Grimmett, R. F. and Shirley Kan, S. (2005) European Union's Arms Embargo on China: Implications and Options for US Policy, CRS Report for Congress, 27 May, Washington, DC: Library of Congress.

Baker, P. (2002) 'Human rights, Europe and the People's Republic of China', China Quarterly 169 (March): 45-64.

Bauer, S. (2004) 'The EU Code of Conduct on Arms: enhancing the accountability of arms export policies?', European Security 12: 129-47.

Bauer, S. and Bromley, M. (2004) The European Code of Conduct on Arms Exports: Improving the Annual Report, SIPRI Policy Paper No. 8, Stockholm: Stockholm International Peace Research Institute.

BBC (2007) BBC News Online (International), 'EU stands by China arms embargo', 18 January; accessed at http://news.bbc.co.uk/2/hi/asia-pacific/6272263.stm, 18 September 2007.

Berkofsky, A. (2006) 'The EU-China strategic partnership: rhetoric versus reality', in M. Zaborowski (ed.) Facing China's Rise: Guidelines for an EU Strategy, Chaillot Paper No. 94, Paris: European Union Institute for Security Studies, pp. 103-15.

Bersick, S. (2006) 'Strategic considerations in the US-China relationship and the role of European soft power', Asia-Europe Journal 4(2): 251-64.

Bitzinger, R. A. (2004) 'A prisoner's dilemma: the EU's China arms embargo', China Brief 4(13), 24 June, pp. 1-3.

Boese, W. (2005) 'EU retains China arms embargo', Arms Control Today 35(1) (January/February), pp. 36-7.

Brooks, S. G. and Wohlforth, W. C. (2005) 'Hard times for soft balancing', International Security 30(1): 72-108.

Butler, C. (2006) 'UK-Asian strategic alliances in the defence manufacturing industry', Asia-Europe Journal 4(1): 43-52.

Callahan, W. A. (2007) 'Future imperfect: the European Union's encounter with China (and the United States)', Journal of Strategic Studies 30(4): 777807.

Casarini, N. (2006) The Evolution of the EU-China Relationship: From Constructive Engagement to Strategic Partnership, Occasional Paper No. 64, Paris: European Union Institute for Security Studies.

Casarini, N. (2007) 'The international politics of the Chinese arms embargo issue', International Spectator, 42(3):371-89.

Chambers, M. R. (2006) 'Rising China: the search for power and plenty', in A. J. Tellis and M. Wills (eds) Strategic Asia 2006-2007, Seattle: National Bureau of Asian Research, pp. 65-105.

Christensen, T. J. (2001) 'China', in R. J. Ellings and A. L. Friedberg (eds) Strategic Asia 2001-2002, Seattle: National Bureau of Asian Research, pp. 27-69.

Deng, Y. (2007) 'Remoulding great power politics: China's strategic partnerships with Russia, the European Union, and India', Journal of Strategic Studies 30(4): 836-903.

EC (2003) Commission of the European Communities, A Maturing Partnership: Shared Interests and Challenges in EU-China Relations (Commission Policy Paper for Transmission to the Council and the European Parliament), Brussels, 10 September, $\operatorname{COM}(2003) 533$ final. 
(2006) Commission of the European Communities, EU-China: Closer Partners, Growing Responsibilities (Communication from the Commission to the Council and the European Parliament), Brussels, 24 October, COM (2006) 632 final.

The Economist (2005) 'Arms exports to China', The Economist, 24 February; accessed at http://www.economist.com/world/europe/displaystory.cfm?story_id= E1_PSbbPbJ, 11 September 2007.

EP [European Parliament] (2005) 'Arms export code must be binding', NewsPress Service, 17 November; accessed at http://www.europarl.europa.eu/ news/expert/infopress_page/031-22, 17 January 2007.

_ (2006) 'China: Foreign Affairs Committee calls for progress on human rights', News-Press Service, 31 August; accessed at http://www.europarl.europa.eu/ news/expert/briefing_page/9654-24, 17 January 2007.

Erickson, J. (2005) The Contradictory Pressures and Goals of European Arms Transfer Policy: The China Embargo Case, Research Paper, Political Economy Research Group, School of Government, New York: Cornell University.

EU (2003) 'EU China summit concludes agreements on industrial policy, Galileo and tourism', 3 November; accessed at http://ec.europa.eu/comm/external_ relations/china/summit/jp_1103.htm, 1 March 2007.

_ (2007a) 'The EU's relations with China: economic and trade relations'; accessed at http://ec.europa.eu/comm/external_relations/china/intro/ economic_trade.htm, 1 March 2007.

_ (2007b) 'The EU's China policy'; accessed at http://ec.europa.eu/ comm/external_relations/china/intro/index.htm, 1 March 2007.

EU Business (2007) 'EU president, Germany reassures Japan on China arms embargo', EU Business, 10 January; accessed at http://www.eubusiness.com/ news_live/1168444821.66/, 30 October 2007.

Ferrero-Walder, B. (2005) 'The EU, China and the quest for a multilateral world'; accessed at http://europa.eu.int/comm/external_relations/ news/ferrero/2005/sp05_414.htm, 30 October 2007.

Fullbrook, D. (2007) 'China's strategic Southeast Asian overture', Japan Focus: An Asia Pacific E-Journal, 6 March; accessed at http://japanfocus.org/products/ details/2372, 22 March 2007.

Garver, J. W. (2005) 'China's influence in Central and South Asia: is it increasing?', in D. Shambaugh (Ed.) Power Shift: China and Asia's New Dynamics, Berkeley: University of California Press, pp. 205-28.

Gill, B. (2005) 'China's regional security strategy', in D. Shambaugh (ed.) Power Shift: China and Asia's New Dynamics, Berkeley: University of California Press, pp. 247-66.

_ (2007) Rising Star: China's New Security Diplomacy, Washington, DC: Brookings Institution Press.

Glaser, B. S. and Medeiros, E. S. (2007) 'The changing ecology of foreign policymaking in China: the ascension and demise of the theory of "peaceful rise", China Quarterly 190 (June): 291-310.

Godement, F. (2006) 'Neither hegemon nor soft power: China's rise at the gates of the West', in M. Zaborowski (ed.) Facing China's Rise: Guidelines for an EU Strategy, Chaillot Paper No. 94, Paris: European Union Institute for Security Studies, pp. 51-71.

Golden, S. (2006) 'Socio-cultural aspects of the relationship between the EU and East Asia, with particular reference to China', Asia-Europe Journal 4(2): 26594.

Goldstein, A. (2001) 'The diplomatic face of China's grand strategy: a rising power's emerging choice', China Quarterly 168 (December): 835-64.

- (2005) Rising to the Challenge: China's Grand Strategy and International Security, Stanford: Stanford University Press. 
Grimmett, R. F. and Papademetriou, T. (2005) European Union's Arms Control Regime and Arms Exports to China: Background and Legal Analysis, CRS Report for Congress, 1 March, Washington, DC: Library of Congress.

Hale, D. and Hale, L. H. (2003) 'China takes off', Foreign Affairs 82(6): 36-54.

Hartfiel, R. and Job, B. L. (2007) 'Raising the risks of war: defence spending trends and competitive arms processes in East Asia', The Pacific Review 20(1): 1-22.

House (2005) US House of Representatives, 'Foreign Relations Authorisation Act, fiscal years 2006, 2007', Sections 903-909; accessed at http://thomas.loc.gov/ cgi-bin/query/F?c109:3:./temp/ c109ROiHJd:e269849, 21 March 2007.

Hughes, C. R. (2005) 'Nationalism and multilateralism in Chinese foreign policy: implications for Southeast Asia', The Pacific Review 18(1): 119-35.

Hughes, C. W. (2005) Japan's Re-emergence as a 'Normal' Military Power, London: IISS/Routledge.

Huo, Z. (2005) On China-EU Strategic Relationship, Beijing: China Institute of International Studies; accessed at http://www.ciis.org.cn/item/2005-0407/50919.html, 11 September 2007.

Jia, Q. (2005) 'Peaceful development: China's policy of reassurance', Australian Journal of International Affairs 59(4): 493-507.

_ (2006) 'One administration, two voices: US China policy during Bush's first term', International Relations of the Asia-Pacific 6(1): 23-36.

Johnston, A. I. (2003) 'Is China a status quo power?', International Security 27(4): 5-56.

Jones, S. G. and Larrabee, F. S. (2006) 'Let's avoid another trans-Atlantic feud', Rand Newsroom Commentary, 13 January; accessed at http://www.rand.org/ commentary/011306IHT.html, 17 January 2007.

Kan, F. Y. (2004) 'East Asia in a unipolar international order and Europe's role in the region', Asia-Europe Journal 2(4): 497-522.

Kemenade, W. (2007) Jamestown Foundation, 'Between Beijing and Paris: from abnormally good to more normal', China Brief 7(15), 26 July; accessed at http://www.jamestown.org/china_brief/article.php?articleid=2373575, 30 October 2007.

Kogan, E. (2005) The European Union Defence Industry and the Appeal of the Chinese Market, Vienna: Schriftenreihe der Landesverteidigunsakademie-Studien und Berichte zur Sicherheitspolitik.

Lampton, D. M. (2005) 'China's rise need not be at America's expense', in D. Shambaugh (ed.) Power Shift: China and Asia's New Dynamics, Berkeley: University of California Press, pp. 306-29.

Legro, J. W. and Moravcsik, A. (1999) 'Is anybody still a realist?', International Security 24(2): 5-55.

Levy, J. S. (2004) 'What do great powers balance against and when?' in T. V. Paul, J. J. Wirtz and M. Fortmann (eds) Balance of Power Theory Revisited: Theory and Practice in the Twenty-First Century, Stanford: Stanford University Press, pp. 29-52.

Loewen, H. (2007) 'East Asia and Europe: partners in global politics?', Asia-Europe Journal 5(1): 23-31.

Mastanduno, M. (2005) 'Hegemonic order, September 11, and the consequences of the Bush revolution', International Relations of the Asia-Pacific 5(2): 177-96.

Moeller, K. (2002) 'Diplomatic relations and mutual strategic perceptions: China and the European Union', China Quarterly 169 (March): 10-34.

— (2006) 'Europe's policy: neither multipolar nor multilateral', in G. Wacker (ed.) China's Rise: The Return of Geopolitics, SWP Study 53, Berlin: Stiftung Wissenschaftund Politik, pp. 68-74.

MOFA [Ministry of Foreign Affairs, People's Republic of China] (2003) 'China's EU policy paper', 13 October; accessed at http://www.fmprc.gov.cn/eng/ topics/ceupp/t27708.htm, 1 March 2007. 
(2004) 'China's views on the development of multipolarisation', $16 \mathrm{Au}$ gust; accessed at http://www.chinaembassy.org.zw/eng/zt/zgdwzc/t149683.htm, 12 March 2007.

- (2006) Wen Jiabao, 'Deepen Asia-Europe cooperation to jointly meet challenges', 10 September; accessed at http://www.fmprc.gov.cn/eng/ wjdt/zyjh/t272762.htm, 17 January 2007.

- (2007) 'Vice Foreign Minister Yang Jiechi attends and addresses U.S.-EUChina Dialogue Project', 14 January; accessed at http://www.fmprc.gov.cn/ eng/zxxx/t298267.htm, 1 March 2007.

Odgaard, L. and Biscop, S. (2006) 'The EU and China: partners in effective multilateralism?', paper presented at the Conference on the International Politics of EU-China Relations, London, 20-21 April.

OJ (2005) 'Seventh Annual Report According to Operative Provision 8 of the European Union Code of Conduct on Arms Exports', Official Journal of the European Union 2005/C 328, 23 December.

- (2006) 'Eighth Annual Report According to Operative Provision 8 of the European Union Code of Conduct on Arms Exports', Official Journal of the European Union 2006/C 250, 16 October.

Oswald, F. (2006) 'Soft balancing between friends: transforming transatlantic relations', Debate 14(2): 145-61.

Pape, R. A. (2005) 'Soft balancing: how states pursue security in a unipolar world', International Security 30(1): 7-45.

Patten, C. (2005) Not Quite the Diplomat: Home Truths about World Affairs, London: Penguin/Allen Lane.

Paul, T. V. (2004) 'The enduring axioms of balance of power theory', in T. V. Paul, J. J. Wirtz and M. Fortmann (eds) Balance of Power Revisited: Theory and Practice in the Twenty-first Century, Stanford: Stanford University Press, pp. 1-29.

Pei, M. (2006) 'Can economic growth continue without political reform?', in A. J. Tellis and M. Wills (eds) Strategic Asia 2006-2007: Trade, Interdependence and Security, Seattle and Washington, DC: National Bureau of Asian Research, pp. 303-33.

Piper, J. R. (2005) The Major Nation-states in the European Union, New York: Pearson Longman.

Pomper, M. A. (2005) 'U.S., Israel reach China arms deal', Arms Control Today 35(7) (September), p. 34.

Record, F. C. (2006) 'Hearing testimonies: US-China Economic and Security Review Commission', 17 March; accessed at http://www.uscc.gov/hearings/ 2006hearings/written_testimonies/06_03_16_17wrts/06_03_16_17_record.pdf, 21 March 2007.

Roy, D. (2003) 'China's pitch for a multipolar world', Asia-Pacific Security Studies 2(1): 1-4.

Sandschneider, E. (2002) 'China's diplomatic relations with the states of Europe', China Quarterly 169 (March): 33-45. (2006) 'Is China's military modernisation a concern for the EU?', in M. Zaborowski (ed.) Facing China's Rise: Guidelines for an EU Strategy, Chaillot Paper No. 94, Paris: European Union Institute for Security Studies, pp. 3951.

Scott, D. (2007) 'China and the EU: a strategic axis for the twenty-first century?', International Relations 21(1): 23-45.

Shambaugh, D. (2004a) 'China and Europe: the emerging axis', Current History 103(674): $243-8$.

- (2004b) 'China engages Asia', International Security 29(3): 64-89.

- (2005a) 'Introduction: the rise of China and Asia's new destiny', in D. Shambaugh (ed.) Power Shift: China and Asia's New Dynamics, Berkeley: University of California Press, pp. 1-23. 
(2005b) 'The new strategic triangle: US and European reactions to China's rise', Washington Quarterly 28(3): 7-25.

Shih, C. Y. (2005) 'Breeding a reluctant dragon: can China rise into partnership and away from antagonism?', Review of International Studies 31(4): 755-74.

Solana, J. (2003) A Secure Europe in a Better World: European Security Strategy, Brussels: European Union.

Stumbaum, M. (2007) 'Opportunities and limits of EU-China security cooperation', International Spectator 42(3): 351-70.

Swain, M. D. and Tellis, A. J. (2000) Interpreting China's Grand Strategy: Past, Present, and Future, Santa Monica: Project Air Force and Rand.

Tang, S. C. (2005) 'The EU's policy towards China and the arms embargo', AsiaEurope Journal 3(3): 313-21.

Umbach, F. (2004) 'EU's links with China pose new threat to transatlantic relations', European Affairs (Spring), pp. 1-8.

Van der Geest, W. (2006) 'Shaping factors of EU-East Asia relations', Asia-Europe Journal 4(2): 131-49.

Van Ness, P. (2002) 'Hegemony, not anarchy: why China and Japan are not balancing US unipolar power', International Relations of the Asia-Pacific 2(1): 131-50.

Walt, S. M. (2005) Taming American Power: The Global Response to U.S. Primacy, New York: W. W. Norton.

Waltz, K. L. (1993) 'The emerging structure of international politics', International Security 18(2): 44-79.

— (2000) 'Structural realism after the Cold War', International Security 25(1): $5-41$.

Weinrod, W. B. (2006) 'US and European approaches to China', Mediterranean Quarterly 17(2): 17-31.

Weitz, R. (2006) 'Renewing central Asian partnerships', NATO Review (Autumn); accessed at http://www.nato.int/docu/review/2006/issue3/english/analysis2.html, 14 March 2007.

Wen, J. (2005) 'Vigorously promoting comprehensive partnership between China and the European Union', China-Europe Investment and Trade Forum, 12 May; accessed at http://www.chinamission.be/eng/zt/t101949.htm, 14 March 2007.

Winn, N. (2003) 'Towards a common European security and defence policy? The debate on NATO, the European army and transatlantic security', Geopolitics $8(2): 47-68$

Wulf, H. (2004) 'Have the European Union and its member states put arms control on the back burner?', European Security 12: 113-28.

Zaborowski, M. (ed.) (2006a) Facing China's Rise: Guidelines for an EU Strategy, Chaillot Paper No. 94, Paris: European Union Institute for Security Studies. (2006b) 'US-China relations: running on two tracks', in M. Zaborowski (ed.) Facing China's Rise: Guidelines for an EU Strategy, Chaillot Paper No. 94, Paris: European Union Institute for Security Studies, pp. 83-103.

Zhang, Y. and Tang, S. (2005) 'China's regional strategy', in D. Shambaugh (ed.) Power Shift: China and Asia's New Dynamics, Berkeley: University of California Press, pp. 48-71.

Zhang, Z. (2003) 'Beijing calling', NATO Review (Autumn); accessed at http://www.nato.int/docu/review/2003/issue3/english/special.html, 14 March 2007.

Zhao, Q. and Liu, G. (2007) 'The challenges of a rising China', Journal of Strategic Studies 30(4-5): 585-608.

Zheng, B. (2005) “'Peacefully rising” to great-power status', Foreign Affairs 84(5): 18-25.

Zweig, D. and Bi, J. (2005) 'China's global hunt for energy', Foreign Affairs 84(5): 25-39. 